\title{
Article
}

\section{The Management of Agriculture Plastic Waste in the Framework of Circular Economy. Case of the Almeria Greenhouse (Spain)}

\author{
Francisco José Castillo-Díaz ${ }^{1}\left(\mathbb{D}\right.$, Luis Jesús Belmonte-Ureña ${ }^{2, *}$, Francisco Camacho-Ferre ${ }^{1}$ (D) \\ and Julio César Tello-Marquina ${ }^{1}$ \\ 1 Research Centre CIAIMBITAL, Department of Agronomy, University of Almería, 04120 Almería, Spain; \\ Franjcd95@hotmail.com (F.J.C.-D.); fcamacho@ual.es (F.C.-F.); jtello@ual.es (J.C.T.-M.) \\ 2 Research Centre CIAIMBITAL, Department of Economy and Business, University of Almería, \\ 04120 Almería, Spain \\ * Correspondence: lbelmont@ual.es
}

\section{check for}

updates

Citation: Castillo-Díaz, F.J;;

Belmonte-Ureña, L.J.; Camacho-Ferre,

F.; Tello-Marquina, J.C. The

Management of Agriculture Plastic

Waste in the Framework of Circular

Economy. Case of the Almeria

Greenhouse (Spain). Int. J. Environ.

Res. Public Health 2021, 18, 12042.

https://doi.org/10.3390/

ijerph182212042

Academic Editor: Paul B. Tchounwou

Received: 3 October 2021

Accepted: 13 November 2021

Published: 16 November 2021

Publisher's Note: MDPI stays neutral with regard to jurisdictional claims in published maps and institutional affiliations.

Copyright: (c) 2021 by the authors. Licensee MDPI, Basel, Switzerland. This article is an open access article distributed under the terms and conditions of the Creative Commons Attribution (CC BY) license (https:// creativecommons.org/licenses/by/ $4.0 /)$.

\begin{abstract}
In recent decades, ecosystems have suffered diverse environmental impacts caused by anthropogenic activities, including the dumping of plastic waste. This situation has prompted the European Union to introduce a new policy based on the circular economy. In this study, the present state and future perspectives on the generation and treatment of plastic waste in the intensive agriculture of Almeria (Spain) are analyzed. This activity generates $1503.6 \mathrm{~kg} \cdot \mathrm{ha}^{-1} \cdot \mathrm{year}^{-1}$, on average, of plastic waste with an approximate treatment cost of $0.25 € / \mathrm{kg}$. The present study shows that the volume of plastic waste from intensive agriculture in Almeria is constantly increasing $(48,948.2$ tons in 2020/21) and it is suggested that the current management system does not meet the needs of the sector. Although it presents great opportunities for improvement under the framework of the circular economy. Furthermore, this work reports a direct relationship between the price of the raw materials needed for the production of plastic and the volume of recycled plastics. For this reason, it would be advisable for the administration to consider the implementation of a tax rebate system for the sector and specifically when the petroleum derivatives used to manufacture plastic are less expensive, and the recycling option is not so attractive.
\end{abstract}

Keywords: circular economy; waste management; agriculture; plastic waste; sustainable development

\section{Introduction}

Anthropogenic activities have deteriorated natural ecosystems while compromising their sustainability [1,2]. Among these activities, the production of food and fiber required by humans has led to the transformation of ecosystems into agricultural systems [3], which alters their functionality and organization [4]. These parameters have changed with every agricultural revolution triggering an increase in crop yields [5-10]. This has resulted in an ever-increasing consumption of natural resources [11]. The metamorphosis of agricultural systems has led to a shift from traditional subsistence agriculture to commercial agriculture, especially in the most economically developed countries [12]. This dynamic is causing serious environmental, social, and economic imbalances in some cases [2,13-16]. However, despite the changes that have taken place, agriculture continues to have a family-based structure in most countries and it is a major source of employment as well [17].

Agricultural evolution has led farming systems to demand inputs that are linked to plastic polymers [18-22]. The characteristics of plastic elements make them one of the primary pollutants in ecosystems, mainly due to their tendency to fragment into small particles, such as microplastics and nanoplastics [23-28]; and by the emission, due to ultraviolet radiation from the sun, of some chemical substances that are added during the manufacturing process (additives) to improve the characteristics of the plastic (e.g., biophenol) $[29,30]$. Unfortunately, the dumping of plastic waste is a common practice and marine ecosystems have experienced the highest incidence of dumping [31,32], which 
affects their flora and fauna [25], and its associated microbiome [33]; as well as their physical environment [34]. Negative externalities have also affected terrestrial ecosystems and agriculture has become a source of pollution, particularly in the case of intensive agriculture due to the massive use of inputs made from plastics [18,22]. Thus, poor management of this material can lead to the accumulation of microplastics in soil profiles [35] or to the internal infestation of some animals intended for human consumption when fed with agricultural biomass [36], can lead to the accumulation of polymers and chemicals in plant and animal tissues that can be transferred to the food chain $[30,37,38]$. This may pose a risk to the health of living beings, including humans $[26,30,39]$. For example, some additives added to plastics have been observed to act as endocrine disruptors (e.g., biophenol) [29,30].

In most cases, the lack of sustainability generated by the conventional agricultural production process contravenes the United Nations (UN) principles for "Sustainable or Lasting Development" formulated in 1992 [40]. In September 2015, the UN approved the 2030 Agenda for Sustainable Development addressing the economic, social, and environmental aspects of greatest global interest [41], which includes the sustainability of agricultural systems [42]. The Agenda has guided the development of various strategies and regulatory bases of its members. In addition, the European Union (EU) proposed the European Green Pact as the central axis of this change to implement a long-term production model based on sustainability [43] by replacing its current linear economic model with an alternative model, such as the circular economy (CE). In 2015, the foundations were laid for a European Circular Economy Action Plan to promote the reduction, reuse, and recycling of inputs used in the various production systems to minimize the waste generated. It details seven lines of action to address the problem generated by waste, which includes plastics [44]. This action plan underwent a revision in 2020 and the lines of action proposed in the previous plan have been completed [45]. These new measures aim to reduce the pollution caused by plastics and they include a ban on single-use plastics, which affects the materials used in food marketing [46]. In addition, the EU has recently reformulated its waste management regulations affecting the treatment of agricultural plastics (hazardous and non-hazardous) [47-50]. These regulations make special mention of the reuse of waste generated in production processes by transforming it into by-products.

Intensive agriculture under plastic, or in greenhouses, is very important on a European scale. More than $43 \%$ of the greenhouse area in the world is located in the EU, i.e., about 175,000 ha of the 405,000 ha identified worldwide [51]. Spain, France, Greece, Italy, and the Netherlands are the areas of greatest significance and Spain has the largest area of protected cultivation with 71,783 ha. Protected agriculture is not homogeneously distributed in the country but rather concentrated in agricultural areas [52]. Thus, the province of Almeria is the largest agricultural region of protected crops in Spain reaching 32,554 ha of greenhouses in 2020. These are mostly concentrated into two agricultural regions (Campo de Dalías and Bajo Andarax-Campo de Nijar) [53] that are socioeconomic pillars in the territory [54,55]. Despite being systems that typically consume large amounts of resources [51], they are known for their efficient use of these resources thanks to the technology involved in different production processes [56]. However, they also generate high amounts of different kinds of waste [18,22,57], plastics being one of them [21,22]. For some years now, the Food and Agriculture Organization of the United Nations (FAO) has recommended a series of practices in protected agriculture with the aim of mitigating climate change and promoting the sustainability of the systems [56]. This has been coupled with an effort made by the EU to promote the establishment of "circular horticulture" in agriculture under plastic, which has expanded significantly in its territory [51]. Indeed, the intensive greenhouse horticultural sector has been described as a suitable place for its implementation [57-61]. However, due to the recent introduction of various strategies and action plans, the establishment of circular horticulture is considered one of the biggest challenges of the agricultural systems, including those located in the province of Almeria [62].

Due to the socio-economic importance of greenhouse agriculture in Almeria and its huge need for plastics, it is essential to identify the opportunities of the agricultural system 
to obtain its production under the principles of CE. Thus, the objectives of this work have been the following:

1. To calculate the production of agricultural plastic waste or by-products in the greenhouse fruit and vegetable production system in Almeria along with the current management system.

2. Identify and qualitatively assess the various existing alternatives for the management of agricultural plastic waste along with the opportunities supported by the current regulatory framework that may exist for farmers and managers.

3. To evaluate the relationship between the price of oil and the amount of recycled plastic in the member States of the EU.

\section{Materials and Methods}

\subsection{General and Specific Stages of the Research Process}

For this research, a compilation, classification, verification, and detailed analysis of the information obtained from various studies, technical reports, regulations, and statistics from various public and private organizations was carried out. These organizations had authority and/or relationships with the subject matter addressed and these ranged from local to international. In addition, telephone consultations with numerous departments of regional and local public institutions in charge of managing the data of interest were made to validate the information gathered from their official web pages. Telephone or e-mail interviews were conducted with different agents involved in the production, marketing, or management of agricultural plastics with the aim of expanding and verifying the information found in the bibliography.

The analysis of the literature on plastic waste/by-products was carried out using the Scopus and Web of Science (WoS) databases. This procedure has already been used in other studies related to waste management in agriculture [58] resorting in some cases to the use of specialized software for information processing (Excel Microsoft 365, SigmaPlot 14.0 and SPSS Statistics v.26). Table 1 shows the specific stages of the study.

Table 1. Specific methodology and sources of information consulted.

\begin{tabular}{|c|c|c|c|}
\hline & Objetives & Procedure & Source of Information \\
\hline 1. & $\begin{array}{l}\text { To estimate the production of agricul- } \\
\text { tural plastic waste or by-products in the } \\
\text { greenhouse fruit and vegetable produc- } \\
\text { tion system in the province of Almeria, } \\
\text { together with the current management } \\
\text { system. }\end{array}$ & $\begin{array}{l}\text { Review and analysis of technical studies and } \\
\text { scientific research. } \\
\text { Contrast of information found by means of the } \\
\text { agents qualified to do so. } \\
\text { Processing, analysis, and graphic } \\
\text { representation of the results (Excel Microsoft } \\
\quad 365 \text { and SigmaPlot 14.0). }\end{array}$ & $\begin{array}{c}\text { Official websites of public agencies: CAGPDR, } \\
\text { MAPA and ERDF. } \\
\text { Websites of public and private research centers: } \\
\text { FC and CIAIMBITAL. } \\
\text { Scientific literature obtained from search } \\
\text { engines such as Scopus and Web of } \\
\text { Science (WoS). }\end{array}$ \\
\hline \multirow[t]{2}{*}{2.} & \multirow{2}{*}{$\begin{array}{l}\text { Identify and qualitatively assess the var- } \\
\text { ious existing alternatives for the man- } \\
\text { agement of agricultural plastic waste, to- } \\
\text { gether with the opportunities that may } \\
\text { exist for farmers and managers, which } \\
\text { are supported by the current regulatory } \\
\text { framework. }\end{array}$} & $\begin{array}{l}\text { Identification of key agents (public and } \\
\text { private organizations). }\end{array}$ & $\begin{array}{l}\text { Information obtained from interviews with } \\
\text { CA, IEPA, and ES. } \\
\text { Official websites of public and private } \\
\text { organizations: CAGPDR, BOE, EUR-lex, } \\
\text { MAPA, and SIGFITO. }\end{array}$ \\
\hline & & $\begin{array}{l}\text { Review and analysis of technical studies and } \\
\text { scientific research. Processing, analysis, and } \\
\text { graphical representation of the results (Excel } \\
\text { Microsoft } 365 \text { and SigmaPlot 14.0). } \\
\text { Review and analysis of regulatory bases and } \\
\text { strategies at local, regional, national, and } \\
\text { international levels. }\end{array}$ & $\begin{array}{l}\text { Websites of public and private research centers: } \\
\text { IFAFA, CIAIMBITAL, ERDF, and FC. } \\
\text { Scientific literature obtained from search } \\
\text { engines such as Scopus and } \\
\text { Web of Science (WoS). }\end{array}$ \\
\hline
\end{tabular}


Table 1. Cont.

\begin{tabular}{|c|c|c|c|}
\hline & Objetives & Procedure & Source of Information \\
\hline \multirow[t]{2}{*}{3.} & \multirow[t]{2}{*}{$\begin{array}{l}\text { To evaluate the relationship between the } \\
\text { price of oil and the amount of recycled } \\
\text { plastic in the EU Member States. }\end{array}$} & $\begin{array}{l}\text { Review and analysis of official statistics on } \\
\text { crude oil barrel price (series 1987-2020), } \\
\text { percentage of "packing" recycled plastic } \\
\text { (series 1997-2018) (Article 6.1 Directive } \\
\text { 94/62/EC) (consulted on } 17 \text { May 2021) and } \\
\text { percentage of 'light packaging' recycled in } \\
\text { Almería (consulted on } 2 \text { November 2021) }\end{array}$ & $\begin{array}{l}\text { Percentage of "packing" recycled plastic: } \\
\text { Eurostat.Percentage of 'light packaging' } \\
\text { recycled in Almería: CAGPDR. }\end{array}$ \\
\hline & & $\begin{array}{l}\text { Statistical processing, analysis, and graphical } \\
\text { representation of results (Excel Microsoft } 365 \\
\text { and SigmaPlot } 14.0 \text { and SPSS Statistics v.26). }\end{array}$ & $\begin{array}{c}\text { Scientific literature obtained from search } \\
\text { engines such as Scopus and } \\
\text { Web of Science (WoS). }\end{array}$ \\
\hline
\end{tabular}

CAGPDR: Consejería de Agricultura, Ganadería, Pesca y Desarrollo Rural; MAPA: Ministerio de Agricultura, Ganadería y Pesca; FC: Fundación Cajamar; ERDF: European Regional Development Fund, REINWASTE project; FC: Fundación Cajamar; CIAIMBITAL: Centro de Investigación en Agrosistemas Intensivos Mediterráneos y Biotecnología Agroalimentaria de la Universidad de Almería; C. A: Cooperativas Agroalimentarias; IEPA: Engineers in charge of the production process of plastics producing companies; ES: Supply companies; IFAPA: Instituto de Investigación y Formación Agraria y Pesquera; EIA: Energy Information Administration of the United States; Eurostat: European Statistical Office.

\subsection{Details of the Statistical Treatment Performed for Objectives 1 and 2}

After obtaining the data and in view of the variety of publications found on the subject analyzed, the information was processed by synthesizing it into homogeneous groups (i.e., element) as shown by other authors $[18,22]$ and the technical documents of the Reinwaste project [63-67] to ease the representation of the production and management of waste/by-products with the aim of obtaining a single value.

Estimates for Objective 1 were made for commercial "scratch and shake", flat vine and multi-tunnel greenhouses where horticultural crops were grown under the common practices of the area (conventional and organic crops grown on natural soil), from the literature identified in different databases [18,22,63-67]. The data contained in the literature consulted were obtained from an average of plastic waste generated in greenhouses with a surface area of $0.15-1$ ha. In these documents, the total production of plastic waste is presented, without indicating the standard deviation. The data are presented in $\mathrm{kg}^{-\mathrm{ha}}{ }^{-1}$. Finally, the total production of plastic waste per unit area was also calculated and the total production for the total greenhouse area in 2020 was estimated, according to data provided by the regional government [53].

In order to describe the current plastic waste management system in the province of Almeria, direct consultation with the key agents involved in the process (companies) was used. After analyzing the information collected, the plastic waste managers were classified according to the services they offered. Finally, the mean value and standard deviation of the incentives offered to farmers were calculated, as well as the total cost of plastic waste treatment $(€ / \mathrm{kg})$.

The estimate of the average price of plastic waste management was found through the average cost for service, including transportation $(€ / \mathrm{kg})$. Finally, the estimate made in Objective 2 for the cost of alternatives was made through information available in the literature (cost + dose) $[68,69]$, the technical documents of the Reinwaste project $[63,66,67]$ and consultation in specialized supply centers to reach the cost increase in $€ /$ ha.

\subsection{Additional Details of the Methodology for Objective 3}

After obtaining the values of the Brent crude oil price per barrel (C), the average annual value was calculated. This value reflects a change in the variable from the time of origin ( $t$ ) to a monthly lag of twelve months before and after this value $(t-12$ to $t+12)$ to observe the influence of the variable on the annual proportion of recycled plastic (\%). The results were expressed in the unit of origin (\$/barrel). For this purpose, the following expressions were used:

$$
\overline{\mathrm{C}_{\mathrm{t}-\mathrm{n}}}=\frac{\sum_{\mathrm{t}}^{\mathrm{n}} \mathrm{C}}{12}
$$




$$
\overline{\mathrm{C}_{\mathrm{t}+\mathrm{n}}}=\frac{\sum_{\mathrm{t}}^{\mathrm{n}} \mathrm{C}}{12}
$$

$\overline{\mathrm{C}}$ : average price of a barrel of crude oil $\left(\frac{\$}{\text { barrel }}\right)$

$\mathrm{t}$ : time (months)

$\mathrm{n}$ : number of months of lag time $(-12 \leq \mathrm{t} \leq 12)$

The correlation between the values was obtained using Pearson's coefficient (r) with the $\mathrm{F}$ test to check the assumptions necessary for its application. The dependent variable was the amount of 'packing' plastic recycled (\%) and the amount of 'light packaging' recycled in Almería (plastic, briks and cans; \%) and the independent variables were the different annual prices of a barrel of crude oil $(t-12-t+12 ; \$ /$ barrel $)$. The 27 Member States were then subdivided into two groups (Table 2). The first group included the countries that showed an average Pearson coefficient $(t-12-t+12)$ higher than the EU average (G1). The second group included the territories whose average Pearson coefficient $(t-12-t+12)$ was lower than this average (G2).

Table 2. Subdivision made in the graphical representation of Pearson's coefficient.

\begin{tabular}{cccc}
\hline Group & & Countries & \\
\hline & Czech Republic & Denmark & Luxembourg \\
& Spain & Estonia & Malta \\
& The Netherlands & Ireland & Austria \\
G1 & Slovenia & Greece & Portugal \\
& Sweden & France & Finland \\
& Slovakia & Croatia & \\
& Belgium & Italy & Hungary \\
& Bulgaria & Lithuania & Poland \\
\hline \multirow{2}{*}{ G2 } & Germany & Romania & \\
& Cyprus & Latvia & \\
\hline
\end{tabular}

Source: own elaboration.

\section{Results and Discussion}

3.1. Characterization and Estimation of the Production of Agricultural Plastic Waste in the Productive Sector of Greenhouse Agriculture in Almeria

Plastic is linked to most of the components and techniques used in the production process under protection in Almeria (Table 3). It is present in the covering and natural ventilation systems of greenhouses, irrigation equipment and active climate control, agricultural inputs and disinfection processes. It is also used in auxiliary structures such as irrigation ponds and the marketing of the goods [18,22,59-61,63-67,70-72]. The determination of the generation period of this tyspe of waste is established by the crop cycles with a productive seasonality due to their intrinsic characteristics $[73,74]$ Specifically, it was estimated that around $90 \%$ of agricultural plastic waste is generated in the province of Almeria between August and September [18].

In detail, it was estimated that agriculture under plastic in the province of Almeria generates an amount of plastic of $1503.6 \mathrm{~kg} \cdot \mathrm{ha}^{-1} \cdot \mathrm{year}^{-1}$ in the production of fruits and vegetables (an annual amount in the system of 48,948.2 $\mathrm{t}$ ) (Table 3). The amount of waste from covering elements, soil disinfection, and double roofs of greenhouses can account for up to three-quarters of this amount, the rest being made up of the different inputs used in the agricultural system. The packaging of phytosanitary products was classified as hazardous waste while other waste was not classified as such $[47,48,75,76]$. The increase in the surface area registered in recent years $[53,58]$ would cause an increase in plastic waste or by-products generated in the production process, which is concentrated in a few agricultural districts due to the distribution of the greenhouses. Ninety-one percent of the greenhouse surface area is located in the Campo de Dalías and Bajo Andarax-Campo de Nijar [53]. 
Table 3. Estimation of the production and proportion of agricultural plastic waste/by-products by element and total in the greenhouse production system in the province of Almeria. Values (mean \pm standard deviation).

\begin{tabular}{|c|c|c|c|}
\hline Element & Polymer & 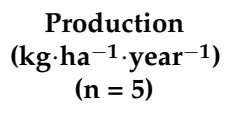 & Proportion (\%) \\
\hline Structure plastic & LDPE, LLDPE, EVA & $707.8 \pm 83.3$ & $47.6 \pm 2.9$ \\
\hline Solarization plastic & LDPE & $224.1 \pm 29.0$ & $15.4 \pm 3.3$ \\
\hline Double roof film & EVA & $135.2 \pm 19.0$ & $8.5 \pm 1.4$ \\
\hline Irrigation system pipes & HDPE, PVC & $113.6 \pm 15.1$ & $7.6 \pm 0.7$ \\
\hline Geotextile netting & PP & $64.4^{1}$ & $3.9^{1}$ \\
\hline Trellising clips & LDPE & $57.9 \pm 24.6$ & $4.1 \pm 2.6$ \\
\hline Trellising raffia & PP & $50.6 \pm 31.9$ & $3.2 \pm 1.9$ \\
\hline Chromotropic traps & LDPE & $30.4 \pm 13.2$ & $2.0 \pm 0.8$ \\
\hline Ventilation netting & HDPE & $23.9 \pm 2.9$ & $1.6 \pm 0.1$ \\
\hline Thermal blankets & LDPE, LLDPE, EVA & $15.3 \pm 6.0$ & $1.0 \pm 0.3$ \\
\hline Fertilizers (bags + containers) & LDPE & $14.7 \pm 5.7$ & $0.9 \pm 0.3$ \\
\hline Returnable plastic containers & HDPE, PS & $14.2 \pm 1.0$ & $1.0 \pm 0.1$ \\
\hline Field boxes & HDPE & $13.6 \pm 11.0$ & $0.7 \pm 0.7$ \\
\hline $\begin{array}{l}\text { Non-returnable plastic } \\
\text { containers }\end{array}$ & HDPE & $9.9 \pm 9.2$ & $0.6 \pm 0.6$ \\
\hline $\begin{array}{l}\text { Plastic containers for } \\
\text { phytosanitary products }\end{array}$ & HDPE & $9.6 \pm 6.7$ & $0.6 \pm 0.4$ \\
\hline Plastic hives & LDPE & $9.2 \pm 0.3$ & $0.6 \pm 0.1$ \\
\hline Gloves & Latex & $4.8 \pm 4.0$ & $0.3 \pm 0.4$ \\
\hline Personal protection suit & HDPE & $4.0 \pm 4.2^{2}$ & $0.3 \pm 0.3^{2}$ \\
\hline $\begin{array}{l}\text { Packaging of biological } \\
\text { control products }\end{array}$ & HDPE & $0.4 \pm 0.3$ & $0.1 \pm 0.0$ \\
\hline Total & - & 1503.6 & - \\
\hline
\end{tabular}

LDPE: low density polyethylene; LLDPE: linear low density polyethylene; EVA: ethylene-vinyl acetate; PVC: polyvinyl chloride; HDPE: high-density polyethylene; PP: polypropylene; PS: polystyrene. N: number of values. ${ }^{1}: \mathrm{n}=1 ;^{2}: \mathrm{n}=2$; source: own elaboration based on data provided by other authors [18] and technical documents of the Reinwaste project [63-67].

However, as in other models of greenhouse agriculture, these elements were formed from seven groups of polymers, such as low (LDPE and LLDPE) and high density polyethylene (HDPE), polypropylene, ethylene-vinyl acetate (EVA), polystyrene and polyvinyl chloride (PVC) [20-22,77-79]. The different types of polyethylene (LDPE, LLDPE and HDPE) and polypropylene made up the largest tonnage of production (96.9\%) (Figure 1). The microplastics obtained from the fragmentation of these polymers cause the greatest impact on the Posidonia oceanica meadows found on the Almeria coast. Its ecosystem shows a significant increase in the deposition of microplastics from greenhouse agriculture. The damage caused is not only due to the fragmentation of the material, but also to the presence of various additives in plastic materials, such as benzyl phthalate [80], which can cause harmful effects on the health of organisms [81].

However, due to the density of the compounds, the volume occupied by polystyrene increased significantly from $0.4 \%$ of the mass to $25.6 \%$ of the volume of plastics generated. This material is mainly generated in the raising of seedlings used in agriculture since it is the main component of the trays used in seedbeds. Thus, the Almeria production system generates between 10.3 and $15.8 \mathrm{~g}$ of plastic per kilogram of product (not including the containers used in marketing), which is less than the figure of $20 \mathrm{~g}$ observed in other sheltered systems [21]. 


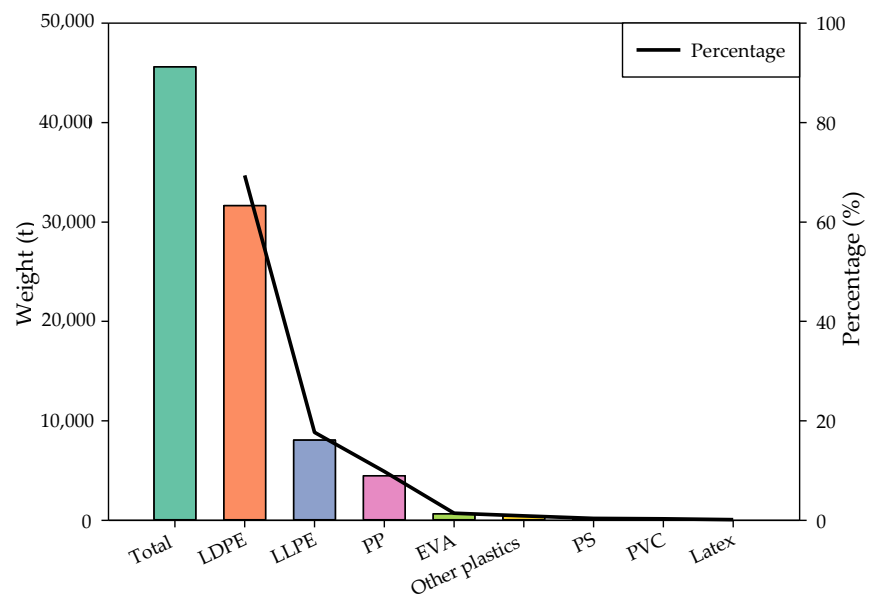

(a)

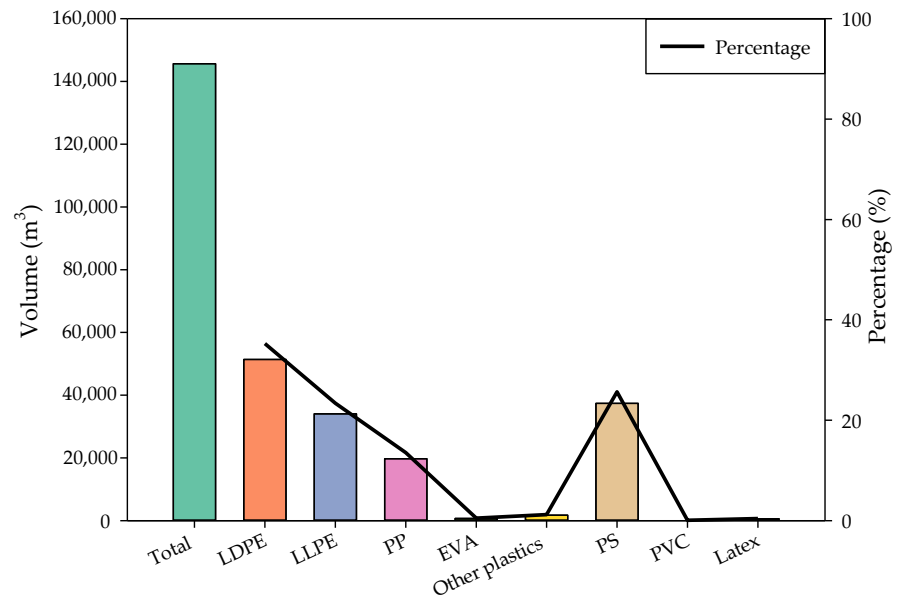

(b)

Figure 1. Generation of plastic waste/by-products in the Almeria model subdivided by type of polymer: (a) mass estimation; (b) volume estimation. LDPE: low density polyethylene; LLDPE: linear low density polyethylene; EVA: ethylene-vinyl acetate; PVC: polyvinyl chloride; HDPE: high density polyethylene; PP: polypropylene; PS: polystyrene. Source: own elaboration based on data provided by other authors [22].

\subsection{Management Strategies Used for the Treatment of Plastic Waste from Greenhouses: The Case of the Province of Almeria}

The processing of the plastic waste generated in greenhouses in the province of Almeria has raised significant problems throughout the life of the greenhouse model mainly due to the seasonality of waste production, an increase in the greenhouse surface area, the difficulty to manage some plastic waste or by-products, and the bad disposal practices of some farmers [18,63]. In 2001, the dumping of agricultural waste in natural areas of Andalusia resulted in a health crisis that required a cleanup of the countryside in the region of Almeria. This crisis revealed the need to implement an adequate agricultural waste management and treatment system in the province of Almeria in light of the expansion of its intensive agriculture. Since then, competent public institutions have developed different financing lines and agreements for initiatives aimed at the massive collection of agricultural waste. They have also developed urban and rural cleanup plans, along with a general program to improve the integrated management of agricultural waste $[18,82]$. Despite all efforts, the poor management of agricultural plastic waste or by-products from protected agriculture in the provinces of Almeria, Granada, and Huelva, and the indiscriminate abandonment of these leftovers in natural spaces forced the Government of Andalusia to carry out a campaign to collect greenhouse plastic waste [83-85] in 2018.

Currently, the province of Almeria has more than 25 treatment and recovery centers for hazardous and non-hazardous agricultural plastic waste distributed throughout its territory, most of them located in the western part of the province. In each of these, the storage, waste recovery, or recycling procedures authorized by competent authorities are applied [86]. The necessary decontamination processes are also used for hazardous by-products [76].

Of the farmers who grow crops under shelter in these centers, $96.2 \%$ manage plastic waste and $94 \%$ are involved in hazardous product packaging [87]. Only $10 \%$ of the management centers handle most of the plastic waste generated on farms and they offer a specialized management service. The agricultural plastic waste most readily accepted by the management plants were polyethylene boxes and containers $(80 \%)$, and ventilation nets $(70 \%)$, followed by pipes and thermal blankets $(60 \%)$ (Table 4$)$. In contrast, none of the management centers dealt with gloves, plastic hives, personal protection suits, or chromotropic traps, perhaps as a result of their specialization. Unfortunately, only $30 \%$ of the waste management companies accepted the structure, solarization, and double roof 
plastics, despite the fact that these are the largest fraction in the amount of waste generated in the intensive system. There is a small number of waste management companies handling containers of phytosanitary products and fertilizers used in agriculture. Although management has improved significantly with the implementation of the container take-back system (SIGFITO), to which most manufacturers adhere to, there is still a significant amount of containers that are not delivered to a specific disposal or treatment point [88]. Since 2013, some fertilizer producers have voluntarily joined this integrated treatment system [76], despite not having the regulatory obligation to implement a collective management model or an individual system until 31 December $2024[48,76]$.

Table 4. Management offer, incentive system, and possible treatments of waste/by-products in the Almeria model ( $\mathrm{n}=10)$.

\begin{tabular}{|c|c|c|c|c|c|c|c|c|}
\hline \multirow{3}{*}{ Element } & \multirow{3}{*}{$\begin{array}{c}\text { Management } \\
(\%)^{1}\end{array}$} & \multicolumn{2}{|c|}{ Incentive $^{1}$} & \multicolumn{3}{|c|}{ No Incentive ${ }^{1}$} & \multirow{3}{*}{$\begin{array}{c}\text { Charge } \\
\text { Transporta- } \\
\text { tion Costs } \\
1\end{array}$} & \multirow{3}{*}{$\underset{2}{\text { Destination }}$} \\
\hline & & \multirow{2}{*}{$\begin{array}{l}\text { Proportion } \\
\qquad(\%)\end{array}$} & \multirow{2}{*}{$\begin{array}{c}\text { Remuneration } \\
(€ / \mathrm{kg})\end{array}$} & \multirow{2}{*}{$\begin{array}{c}\text { No } \\
\text { Charge } \\
\begin{array}{c}\text { Proportion } \\
(\%)\end{array}\end{array}$} & \multicolumn{2}{|c|}{ Charge } & & \\
\hline & & & & & $\begin{array}{l}\text { Proportion } \\
(\%)\end{array}$ & $\begin{array}{l}\text { Cost } \\
(€ / \mathrm{kg})\end{array}$ & & \\
\hline Structure plastic & 30.0 & 66.7 & $0.03 \pm 0.01$ & 0.0 & 33.3 & 0.10 & $33.3^{3}$ & $A, B$ \\
\hline Solarization plastic & 30.0 & 0.0 & - & 0.0 & 100.0 & $0.14 \pm 0.05$ & 0.0 & A, B \\
\hline Double roof film & 30.0 & 0.0 & - & 0.0 & 100.0 & $0.14 \pm 0.05$ & 0.0 & $A, B$ \\
\hline $\begin{array}{l}\text { Irrigation system } \\
\text { pipes }\end{array}$ & 60.0 & 16.7 & 0.03 & 66.7 & 16.6 & 0.10 & 0.0 & A \\
\hline Geotextile netting & 50.0 & 0.0 & - & 0.0 & 100.0 & $0.12 \pm 0.01$ & 0.0 & $A, B$ \\
\hline Trellising clips & 20.0 & 0.0 & - & 0.0 & 100.0 & $0.15 \pm 0.07$ & 0.0 & A, B \\
\hline Trellising raffia & 20.0 & 0.0 & - & 0.0 & 100.0 & $0.15 \pm 0.07$ & 0.0 & A, B \\
\hline $\begin{array}{l}\text { Chromotropic } \\
\text { traps }\end{array}$ & $0.0^{6}$ & - & - & - & - & - & - & - \\
\hline Ventilation netting & 70.0 & 0.0 & - & 0.0 & 100.0 & $0.13 \pm 0.03$ & 0.0 & $A, B$ \\
\hline Thermal blankets & 60.0 & 0.0 & - & 0.0 & 100.0 & $0.11 \pm 0.01$ & 0.0 & $\mathrm{~A}, \mathrm{~B}$ \\
\hline Fertilizer bags & 20.0 & 0.0 & - & 50.0 & 50.0 & $0.15 \pm 0.07$ & 0.0 & $A, B$ \\
\hline $\begin{array}{c}\text { Fertilizes } \\
\text { containers }\end{array}$ & 10.0 & 0.0 & - & 0.0 & 100.0 & $0.39^{4}$ & - & $A, B, C^{5}, D$ \\
\hline Plastic containers ${ }^{7}$ & 80.0 & 87.5 & $0.15 \pm 0.03$ & 0.0 & 12.5 & 0.10 & 0.0 & $A, B$ \\
\hline $\begin{array}{l}\text { Containers for } \\
\text { phytosanitary } \\
\text { products }\end{array}$ & 10.0 & 0.0 & - & 0.0 & 100.0 & $0.39^{4}$ & 0.0 & $\mathrm{~A}, \mathrm{~B}, \mathrm{C}^{5}, \mathrm{D}$ \\
\hline Plastic hives & $0.0^{6}$ & - & - & - & - & - & - & A, B \\
\hline Gloves & $0.0^{6}$ & - & - & - & - & - & - & - \\
\hline $\begin{array}{c}\text { Personal protection } \\
\text { suit }\end{array}$ & $0.0^{6}$ & - & - & - & - & - & - & - \\
\hline $\begin{array}{l}\text { Packaging of } \\
\text { biological control } \\
\text { products }\end{array}$ & 10.0 & 0.0 & - & 0.0 & 100.0 & & 0.0 & A \\
\hline $\begin{array}{c}\text { Average } \\
\text { management cost }\end{array}$ & - & - & - & - & - & $0.23 \pm 0.02$ & - & - \\
\hline
\end{tabular}

Source: ${ }^{1}$ : own elaboration; ${ }^{2}$ : own elaboration based on data provided by other authors [18] and technical documents of the Reinwaste project [63-67]; ${ }^{3}$ : only if the amount is higher than $3 \mathrm{t} ;{ }^{4}$ : price included in the cost of the phytosanitary or fertilizer; ${ }^{5}$ : only from containers of products that have agreements with SIGFITO; ${ }^{6}:$ the management facilities consulted do not accept this waste. ${ }^{7}$ : included are returnable plastic containers, non-returnable plastic containers, field boxes and flower pots. A: recycled; B: energy recovery; C: deposit in the SIGFITO container; D: reuse. Transport costs: $100-150 € /$ service.

The farmer pays the management and transport costs of plastic waste. The maximum cost of these services has been estimated at approximately $0.25 €$ for each $\mathrm{kg}$ of plastic waste produced as shown in Table 4. Regarding the integrated packaging management system, the cost is incorporated into the sale price of the input [88], while for other types of 
residue payment is made when the waste is delivered to the authorized disposal facility. Some operators have established economic incentives to motivate the delivery of waste $(0.03-0.15 € / \mathrm{kg})$, although the measure is selective in nature and applies only to some types of waste (mainly from greenhouse coverings, irrigation systems, boxes, and containers).

Subsequently, waste managers commercialize the plastic pellets resulting from the physical recycling processes (extrusion) of these materials [89,90]. However, not all of the by-product obtained meets the quality criteria required by this process, so the remaining fraction can be used for energy recovery due to its high calorific value [64,91-94]. This last method is not considered a recycling protocol $[47,50,95]$. Some containers of phytosanitary products and fertilizers, generally those with a capacity greater than $200 \mathrm{~L}$, are reused by the companies of origin [96]. It should be noted that some authors recommend that urban waste treatment services manage gloves and chromotropic traps [63,65-67], although this measure leads to a regulatory problem because these residues are defined as non-municipal agricultural waste, so this service falls outside of their range of responsibility [97]. In 2018, in the entire Region of Andalusia, only $40.8 \%$ of agricultural plastics were recycled. A total of $43.6 \%$ was recovered for further treatment and $15.6 \%$ was stored for further recovery [98].

Despite the efforts made by the Andalusian Government, the current plastic waste management model does not offer a comprehensive solution for the sector. The selective nature of the management services available forces farmers to resort to multiple entities, which can confuse the producer and also increase transportation costs. It should be noted that the management centers do not make their rates public, thus increasing the number of preliminary steps to be taken by the farmer. For this reason, some associate or commercial entities facilitate this action with a list containing the most relevant information for the management of agricultural plastic waste, including cost, although this is not a widespread practice. On the other hand, some management centers place obstacles in the treatment of certain types of plastic waste (mainly solarization or mulching plastics) due to the dirt adhered to the plastic, an advanced state of degradation, or the mixture with other types of plastic waste. Therefore, it is recommended that the delivery conditions be agreed upon beforehand between the parties involved [20].

Further, the attitude of some farmers can negatively influence the pre-delivery process. It has been reported that a minority of farmers, often older ones, do not perceive plastic management as critically important for the environment and society [21]. This could lead to the relaxation of sorting and cleaning operations for plastic crop residues, and thus make their treatment more difficult [20].

\subsection{Opportunities for Waste Management and Use of Plastic by-Products by the Different Agents Involved: Inclusion in the CE}

In recent years, a strategic framework has been developed and accelerated to promote, prioritize, and favor the recovery of plastic by-products generated in agricultural systems. The action plans have been included under the circular economy strategy $[44,45,99]$, so it is required to establish a circular system that performs an adequate management of plastic waste. Therefore, it is also necessary to favor measures that increase the generation of by-products, the introduction of biodegradable plastic, the reduction of plastic needs, or the adequate management of the waste generated.

Different compostable and biodegradable plastic polymers have been recently developed for agricultural use. Unfortunately, their technological limitation only allows their use in a few productive activities, mainly to replace traditional composts in mulching and mulching raffias. Its characteristics enable it to withstand production cycles of up to nine months, which makes it an ideal replacement for mulching used throughout the crop cycle $[59,65,66,69]$. Other types of biodegradable mulching, such as straw or rice husks, could also be used $[68,69]$. Biodegradable plastic mulches have shown variable effectiveness compared to conventional polyethylene material when used in soil disinfection by the solarization technique $[100,101]$. This could be due to the higher permeability of the compound due to its inability to retain heat and moisture [100]. Repeated monoculture 
can cause reduced plant growth due to soil fatigue [102,103], which increases the need for plastic and disinfection of the agricultural system to avoid significant decreases in production due to the widespread use of solarization in greenhouse agriculture in Almeria [104]. The addition of organic matter [102] or crop diversification [103] can prevent this phenomenon, thus reducing the need for plastic. Some authors have advocated for agricultural biomass as an alternative for organic amendments $[57,60,102]$ or the cultivation of papaya (Carica papaya) as an option to decimate the low pluralization of plant species used in the Almeria model [105]. Likewise, the use of alternative plastics, biodegradable polymers in items such as chromotropic traps, trellising rings [22] or flower pots [106,107], or broader reuse in other agricultural inputs sucha s the packaging of phytosanitary products and fertilizers [18] could also be considered. The implementation of this final option would largely depend on the resistance of the material due to the toxicity of the formulations that must be contained. The use of ultrasound emitters instead of adhesive traps [22] or a ring-free trellising methodology, where the plants are only guided through the trellising raffia [60], has also been considered.

The sale price of compostable and biodegradable materials represents a considerable increase with respect to some traditional options (Table 5), but these materials facilitate the management of plastic by-products by the farmer or the management plant. On the other hand, rice husk mulching, incorporated through mechanical banding, and biodegradable raffia have been the alternatives with the lowest price increase. There has been a rise in the number of subsidies to encourage the use of biodegradable and compostable plastic, mainly in mulching and trellising elements. In 2021, farmers who were not affiliated with a Fruit and Vegetable Producer Organization (FVPO) had access to a subsidy for the replacement of mulching raffia of $419.29 € /$ ha $[76,108]$. Farmers who were affiliated with an FVPO obtained $50 \%$ off their invoice in replacing plastic mulch and $66 \%$ off the replacement of trellising elements $[109,110]$. This has solved a large portion of the cost overrun [111].

Table 5. Economic evaluation for the implementation of available alternatives to plastic for the farmer in the agricultural input market.

\begin{tabular}{|c|c|c|c|c|c|c|c|}
\hline Input & Alternative & $\begin{array}{c}\text { Cost of the } \\
\text { Material (€/ha) }\end{array}$ & Manage & Cost (€/ha) & $\begin{array}{c}\text { Cost Overrun } \\
(€ / \text { ha })\end{array}$ & Subsidy & $\begin{array}{l}\text { Cost Overrun } \\
\text { after Subsidy }\end{array}$ \\
\hline \multirow{9}{*}{ Padding } & Conventional & 849.6 & & & - & - & - \\
\hline & Compostable & 2016.0 & & & 1116.1 & \multirow[b]{2}{*}{$50.0 \%$ of the bill } & 108.1 \\
\hline & Biodegradable & 4152.0 & & & 3252.1 & & 1176.1 \\
\hline & \multirow{4}{*}{ Straw } & \multirow{3}{*}{1933.3} & $\mathrm{E}$ & 1320.0 & 2333.7 & - & 2333.7 \\
\hline & & & $\mathrm{D}$ & 810.0 & 1823.7 & - & 1823.7 \\
\hline & & & EM & 370.0 & 1383.7 & - & 1383.7 \\
\hline & & \multirow{3}{*}{1575.0} & $\mathrm{E}$ & 1320.0 & 1975.4 & - & 1975.4 \\
\hline & \multirow[t]{2}{*}{ Rice husk } & & $\mathrm{D}$ & 810.0 & 1465.4 & - & 1465.4 \\
\hline & & & EM & 370.0 & 1025.4 & - & 1025.4 \\
\hline \multirow{3}{*}{ Trellising raffia } & Conventional & 108.9 & \multirow{3}{*}{\multicolumn{2}{|c|}{$\begin{array}{l}13.6 \\
4.5^{1} \\
4.5^{1}\end{array}$}} & - & \multirow{3}{*}{$\begin{array}{l}- \\
419.2 € / \text { ha o } 66.0 \% \text { of } \\
\text { the bill }\end{array}$} & - \\
\hline & Compostable & 622.2 & & & 504.2 & & $85.1-93.6$ \\
\hline & Biodegradable & 559.2 & & & 441.2 & & $22.1-72.1$ \\
\hline \multirow{3}{*}{ Trellising clips } & Conventional & 130.5 & \multirow{3}{*}{\multicolumn{2}{|c|}{$\begin{array}{c}10.2 \\
6.7 \\
6.7\end{array}$}} & - & - & - \\
\hline & Compostable & 777.9 & & & 643.9 & \multirow{2}{*}{$50.0 \%$ of the bill } & 255.0 \\
\hline & Biodegradable & 659.2 & & & 525.2 & & 196.5 \\
\hline \multirow{3}{*}{$\begin{array}{l}\text { Traceability } \\
\text { system }\end{array}$} & Conventional & - & \multicolumn{2}{|c|}{-} & - & - & - \\
\hline & $\begin{array}{c}\text { Physical ID } \\
\text { document }\end{array}$ & $300.0^{2}$ & \multicolumn{2}{|c|}{-} & 300.0 & - & 300.0 \\
\hline & $\begin{array}{c}\text { Document } \\
\text { registration } \\
\text { system }\end{array}$ & $391.0^{2}$ & \multicolumn{2}{|c|}{-} & 391.0 & - & 391.0 \\
\hline Total & - & - & \multicolumn{2}{|c|}{-} & $2291.8-4779.7$ & - & $626.7-3073.3$ \\
\hline
\end{tabular}

${ }^{1}$ Proportional cost of external management of plant residues; ${ }^{2}$ excluding administrative fee. E: sanding; D: bare soil; EM: mechanical sanding. Source: own elaboration based on data provided by other authors $[68,69]$, documents obtained from the Reinwaste project website $[63,66,67]$ and consultations with specialized supply centers. 
The use of biodegradable plastic, which decomposes naturally [109], or other organic materials (straw, rice husks, etc.) enables farms to self-manage by incorporating them directly into the soil as raw materials for vermicompost or other types of organic fertilizers. These can act as a part of the nutrient source necessary for the crop $[107,112,113]$ as one of the organic components used in soil biodisinfection processes (i.e., biofumigation or biosolarization) or other agricultural by-products, such as biomass [60]. In fact, the use of alternative materials would facilitate the external management of the biomass or the self-management of the material by the producer by separating any type of plastic from the plant remains [66]. This dynamic would reduce labor by not having to separate the trellising elements from the plant remains. In addition, the inoculation of the soil with earthworms has been recommended to facilitate the proliferation of the microbial flora of the soil by facilitating the biodegradation of the plastic [112]. This practice could provide other benefits as several studies have shown that earthworms improve the physicochemical properties of the soil (improvement of infiltration, porosity, structure or nitrogen mineralization, among others), which allows better crop development [114,115]. On the other hand, organic mulches, such as those formed by straw, offer partially analogous benefits. Their use also leads to an increased organic carbon content [68] and the richness of the fungal community in soil [113], although they should be combined with other amendments or nitrogen compounds to avoid an excessive increase in the carbon/nitrogen ratio.

Unfortunately, no type of compostable or biodegradable plastic whose characteristics meet the needs of resistance and transmissibility demanded by the sector has been commercially developed for the structure of greenhouses, although there are public initiatives to promote its proliferation [116]. Nonetheless, the extension of the useful life of roofing plastics, which is already an ongoing study, could be considered to minimize the generation of waste [117].

Despite the available alternatives, the majority of plastic waste or by-products generated in the greenhouse production system in the province of Almeria must be managed through authorized treatment plants. For this reason, measures such as the establishment of a homogeneous system of incentives to encourage the delivery of waste or a traceability system that allows the identification of those producers who carry out plastic spills should be implemented. A control system has been analyzed by public institutions that is based on physical documentation through a waste management contract and an identification document, or through a documentary record using the compulsory operating logbook in which the information on waste management is entered. This system would facilitate the identification of producers who dump waste [67] and should therefore be introduced as a mandatory measure.

After processing the plastic by-product, the waste management companies obtain a material (plastic pellets) that does not meet the quality criteria demanded by the industry in charge of manufacturing plastic greenhouse coverings. The properties of the recycled raw material are far from those of the basic virgin material [118] and its use would considerably increase production costs while requiring a greater amount of additives and slowing down production process [119]. In some cases, it would also reduce the transmissibility of the cover due to the use of plastic pellets obtained from dyed by-products (e.g., black insect-proof netting). Recycled plastic pellets are marketed at a lower price than virgin material and are destined for a market whose demand is expanding due to current European social and political dynamics $[46-48,120]$ that represent an advantageous opportunity for waste managers $[89,120]$. The main destination of these is usually the production of some agricultural elements (e.g., planters) or urban furniture (e.g., outdoor furniture, garbage containers) $[118,121]$, although they could also be used for industrial purposes, drums or household items, among others [90,122]. Due to the requirements of physical recycling, a portion of the plastic by-products could be used to obtain energy through energy recovery [92], but unfortunately this protocol causes the emission of large quantities of greenhouse gases, which leads to questions about its sustainability. Current lines of research have investigated the potential of some larvae of tenebrionids 
(Tenebrio molitor) or lepidoptera (Galleria mellonella) to decompose some plastic polymers, such as polyethylene [123-125], but this technology is still under development.

Finally, the parties involved (administration, managers, and producers) should promote and implement the necessary actions to help improve the current system of managing agricultural plastics. These actions should include encouraging the introduction of alternative materials, promoting environmental awareness campaigns to inform producers about the pre-treatment of plastic by-products (management plants, type of service performed, and cost of the service), and a traceability system that allows the identification of producers who discharge waste. For the latter two measures, information technology can be used through a mobile app as well as expanding the incentive system to all plastic waste and by-products generated to offer an amount close to $0.25 € / \mathrm{kg}$. The last measure is recommended by the EU to encourage the recycling of agricultural plastic waste [99].

3.4. External Influence of the Cost of Oil on the Management of Plastic by-Products: Relationship between the Cost of a Barrel of Brent Oil and the Percentage of "Packing" Plastic

A direct correlation $(p \leq 0.05 ; p \leq 0.01 ; p \leq 0.001)$ was observed between the price of a barrel of oil and the proportion of recycled plastic (Figure 2) from 1997-2018, although the relationship of the variables depended on each particular European territory.

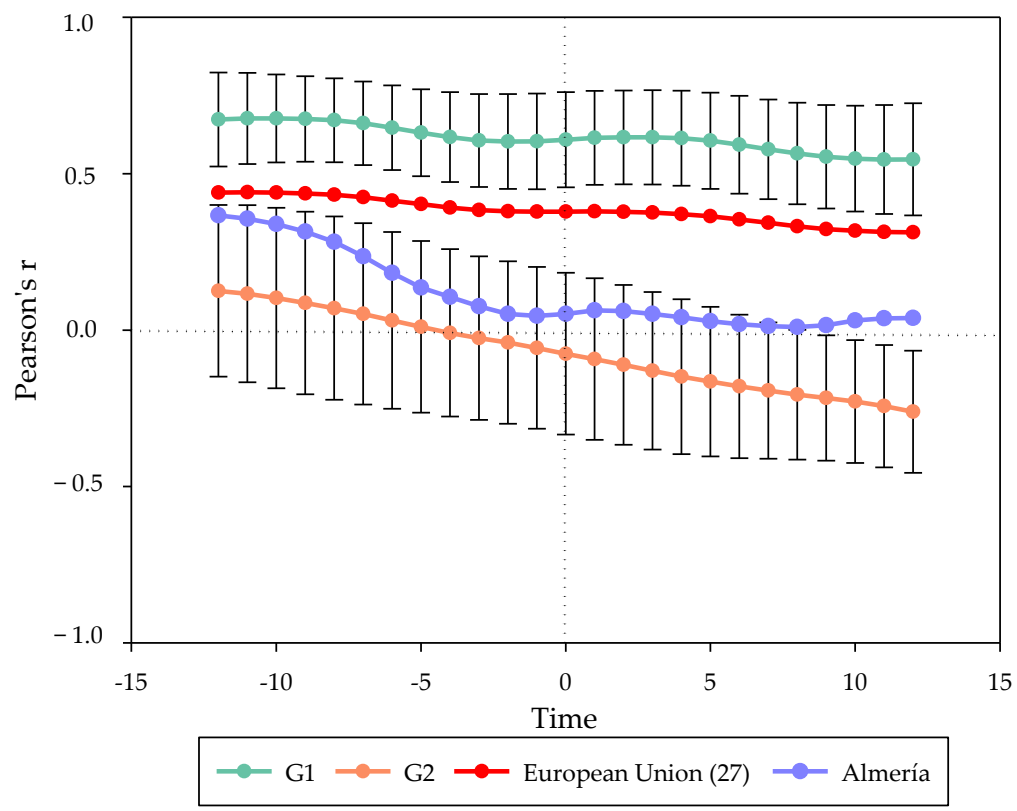

Figure 2. Evolution of Pearson's coefficient in the "packing" plastic ratio versus the monthly cost of a barrel of oil with a monthly lag from $t-12$ to $t+12$. Source: own elaboration based on data obtained from Eurostat (consulted on 17 May 2021), EIA (consulted on 17 May 2021) and CAGPDR (consulted on 2 November 2021).

Thus, the countries belonging to group G1 achieved the highest ratio coefficients with average values ranging from $54.5 \%$ to $67.7 \%$ (Figure 2). These values correspond to the ratio at $t+12$ and $t-11$, respectively. Ireland was the member that showed the highest ratio within this group of territories at $87.9 \%$ (in $t+4$ ). Spain reached a ratio that ranged from $47.9-64.1 \%$, while the province of Almeria has a ratio of $36.7-1.0 \%$.

Member states included in G2 obtained a lower ratio than the European average. As in the case of G1, the highest Pearson's coefficient tended to occur in the range between $t-12$ and $t$. However, from $t-4$ and beyond, the relationship acquired a negative sign (Figure 2). Thus, countries such as Poland, Germany, and Latvia showed an inverse correlation throughout the range of study. Latvia reported the lowest relationship at $t+12$ with $-51.3 \%$. The difference shown between the different EU Member States in the ratio could be a result of a disparate application of their plastic waste management and treatment 
policies [126] where some of the territories would have decoupled their recycling rate from the cost of the raw material.

The results suggest that the Brent price of oil could be an influential variable in the annual planning of European plastic waste management despite targets set by the EU for plastic waste management, which requires its member states to increase the treatment of plastic waste $[47,75]$. Thus, recycled plastic raw material is offered to the market at a lower cost than that obtained from virgin products [127]. The demand for crude oil from the plastic manufacturing sector [128] could be reduced during periods when the cost per barrel of oil remains high by substituting it with recycled plastic material [129]. However, the relationship observed in Figure 2 also poses difficulties in the face of the volatility shown by the price of crude oil. The increased need for additives in the manufacture of plastic and the slowing down of the production process due to the use of recycled plastics [118] may lead to a sharp drop in demand for the by-product in periods when the price of oil remains low, thus limiting the interest of processing plants to apply a recycling treatment to the polymers delivered. The material could just be sorted, to increase the stock and wait for an increase in the demand for by-products; be used for other purposes, such as energy recovery (which is not legally considered a recycling protocol); or be accumulated in landfills in those European countries where it is allowed [47,48,130-132]. In this case, the Administration, within the framework of the $\mathrm{CE}$, must articulate some compensation system that makes the demand for plastic by-products attractive and maintains the demand of manufacturers for the production of new polymers based on recycled material.

\section{Conclusions}

Greenhouse fruit and vegetable agriculture in the province of Almeria uses large amounts of plastic in its productive sector. The annual estimate of this fraction was $1503.6 \mathrm{~kg} \cdot \mathrm{ha}^{-1} \cdot$ year $^{-1}$, which consists of waste and by-products of materials of different origins, but also where the plastics of structure, strips, solarization, and double roof accounted for almost three-quarters of the total. The upward trend in the greenhouse area prompts us to reflect on an increase in the production of waste and by-products in the Almeria model.

Unfortunately, the results of this research suggest that the current system of external management of plastic waste and by-products does not offer a complete solution to the needs of the sector. Despite the significant progress made, plastic dumping still occurs in the natural areas of the province where a negative influence can be seen from all the different parties involved. Nevertheless, the Almeria model would exhibit high potential for improvement since its characteristics seem to facilitate its inclusion within the principles of CE production and thus increase its environmental sustainability. Therefore, it is necessary to facilitate the inclusion of alternative materials and implement the available measures by the Administration to correct the situation, such as establishing a mandatory traceability system in the sector or establishing a system of incentives and compensation to make attractive the delivery of plastic by-products to the manager by the farmer and the demand for recycled plastic chippings by farmers for the production of new materials, respectively. All this under the framework of the EC.

Author Contributions: Conceptualization, F.J.C.-D., L.J.B.-U., F.C.-F. and J.C.T.-M.; data curation, F.J.C.-D., L.J.B.-U., F.C.-F. and J.C.T.-M.; formal analysis, F.J.C.-D., L.J.B.-U., F.C.-F. and J.C.T.-M.; investigation, F.J.C.-D., L.J.B.-U., F.C.-F. and J.C.T.-M.; methodology, F.J.C.-D., L.J.B.-U., F.C.-F. and J.C.T.-M.; project administration, F.J.C.-D., L.J.B.-U., F.C.-F. and J.C.T.-M.; resources, F.J.C.-D., L.J.B.U., F.C.-F. and J.C.T.-M.; software, F.J.C.-D.; supervision, L.J.B.-U., F.C.-F. and J.C.T.-M.; validation, F.J.C.-D., L.J.B.-U. and J.C.T.-M.; visualization, F.J.C.-D., L.J.B.-U., F.C.-F. and J.C.T.-M.; writingoriginal draft, F.J.C.-D.; writing—review and editing, F.J.C.-D., L.J.B.-U., F.C.-F. and J.C.T.-M. All authors have read and agreed to the published version of the manuscript.

Funding: This research received no external funding.

Institutional Review Board Statement: Not applicable. 
Informed Consent Statement: Not applicable.

Data Availability Statement: The data presented in this study are available in this article.

Acknowledgments: The authors wish to thank the Doctoral Program in Protected Agriculture of the University of Almeria.

Conflicts of Interest: The authors declare no conflict of interest.

\section{References}

1. Zhou, J.; Tang, J.; Yang, Y.; Yang, H.; Li, L.; Wu, L. Ecological vulnerability of Lake Basin by integrating human activity indicators based on RS and GIS: A case of Fuxian Lake in Yunnan. J. Phys. Conf. Ser. 2021, 1961. [CrossRef]

2. Región de Murcia. Decreto-Ley 2/2019 de 26 de Diciembre, de Protección Integral del Mar Menor; Agencia Estatal Boletín Oficial del Estado: Madrid, Spain, 2019; Volume 298, pp. 36008-36089. Available online: https://www.boe.es/buscar/doc.php?id=BORM-s2019-90599 (accessed on 18 February 2021).

3. Millennium Ecosystem Assessment. Ecosystems and Human Well-Being: Synthesis; Island Press: Washington, DC, USA, 2005; pp. 1-137, ISBN 1-59726-040-1.

4. Hecht, S.B. La evolución del pensamiento agroecológico. In Agroecología: Bases Científicas para Una Agricultura Sustentable; Altieri, M., Ed.; Editorial Nordan-Comunidad: Montevideo, Uruguay, 1999; Volume 1, pp. 15-30, ISBN 9974-42-052-0.

5. Angelak, A.N.; Zaccaria, D.; Krasilniko, J.; Salgot, M.; Bazza, M.; Roccaro, P.; Jimenez, B.; Kumar, A.; Yinghua, W.; Baba, A.; et al. Irrigation of world agricultural lands: Evolution through the millennia. Water 2020, 12, 1285. [CrossRef]

6. FAO. The Ethics of Sustainable Intensification of Agriculture; Food and Agriculture Organization of the United Nations: Rome, Italy, 2004; pp. 1-34, ISBN 92-5-305067-5.

7. Pei, X. The Agricultural and industrial revolutions in England and China: A view through the lens of dynamic property rights theory. Rural China Int. J. Hist. Soc. Sci. 2020, 17, 194-261. [CrossRef]

8. Trew, A. Endogenous infrastructure development and spatial takeoff in the first industrial revolution. Am. Econ. J. Macroecon. 2020, 12, 44-93. [CrossRef]

9. Andreu, J.P. La difusión de los abonos minerales y químicos hasta 1936: El caso español en el contexto europeo. Hist. Agrar. 1998, 15, 143-182. Available online: http:/ / repositori.uji.es/xmlui/bitstream/handle/10234/123823/1998\%2c_15-4.pdf?sequence= $1 \&$ isAllowed=y (accessed on 19 February 2021).

10. FAO. Towards Zero Hunger 1945-2030; Food and Agriculture Organization of the United Nations: Rome, Italy, $2017 ;$ pp. 1-237.

11. FAO. Background Notes on Sustainable, Productive and Resilient Agro-Food Systems; Food and Agriculture Organization of the United Nations: Rome, Italy, 2019; ISBN 9789251316474.

12. FAO. The State of Food and Agriculture in the World; Food and Agriculture Organization of the United Nations: Rome, Italy, 2017; pp. 1-159, ISBN 978-92-5-109873-8.

13. Pearce, N.J.T.; Lavoie, I.; Thomas, K.E.; Chambers, P.A.; Yates, G. Nutrient enrichment effects are conditional on upstream nutrient concentrations: Implications for bioassessment in multi-use catchments. Ecol. Indic. J. 2021, 124, 107440. [CrossRef]

14. Pedraza, A.C.; Díaz, A.R.; Soto, I.E. Cambios paisajísticos y efectos medioambientales debidos a la agricultura intensiva en la Comarca de Campo de Cartagena-Mar Menor (Murcia). Estud. Geogr. 2015, 76, 473-498. [CrossRef]

15. Ayompe, L.M.; Schaafsma, M.; Egoh, B.N. Towards sustainable palm oil production: The positive and negative impacts on ecosystem services and human wellbeing. J. Clean. Prod. 2021, 278, 123914. [CrossRef]

16. Sumpsi Viñas, J.M. La volatidad de los mercados agrarios y la crisis alimentaria. Rev. Esp. Estud. Agrosociales y Pesq. Minist. Medio Ambient. Rural y Mar. 2011, 229, 1-25. [CrossRef]

17. FAO and IFAD. United Nations Decade of Family Farming 2019-2028. Global Action Plan; Food and Agriculture Organization of the United Nations: Rome, Italy, 2019; pp. 1-78, ISBN 978-92-5-131472-2.

18. Camacho-Ferre, F. Estudio Técnico de Plan de Higiene Rural. Término Municipal de Níjar; Universidad de Almería, Monsul Ingeniería y Níjar Natura: Almería, Spain, 2000; pp. 1-570. Available online: https:/ w3.ual.es/ \{\}fcamacho/Plan\%20higiene\%20global (accessed on 18 February 2021).

19. Tolón-Becerra, A.; Lastra-Bravo, X. La agricultura del poniente almeriense. Diagnóstico e instrumentos de gestión ambiental. M+A Rev. Electrónica Medioambiente UCM 2010, 8, 18-40. Available online: https:/ / www.ucm.es/data/cont/media/www/pag41214/tolonlastraponientealmeriense.pdf (accessed on 20 February 2021).

20. Dupis, I. Residuos Agrarios: Guia para la Intervención Municipal; Asociación Insular de Desarrollo Rural de Gran Canaria: Gran Canaria, Spain, 2009; pp. 1-54, ISBN 978-84-613-4419-2.

21. Galati, A.; Sabatino, L.; Prinzivalli, C.S.; D'Anna, F.; Scalenghe, R. Strawberry fields forever: That is, how many grams of plastics are used to grow a strawberry? J. Environ. Manag. 2020, 276, 111313. [CrossRef]

22. Sayadi-Gmada, S.; Roc, C.; Rojas-Serrano, F.; Garc, R.; Lorbach-kelle, M.B.; Manrique-Gordillo, T. Inorganic waste management in greenhouse agriculture in Almeria (SE Spain): Towards a circular system in intensive horticultural production. Sustainability 2019, 11, 3782. [CrossRef]

23. Bandini, F.; Hchaichi, I.; Zitouni, N.; Missawi, O.; Cocconcelli, P.S.; Puglisi, E.; Banni, M. Bacterial community profiling of floating plastics from South Mediterranean sites: First evidence of effects on mussels as possible vehicles of transmission. J. Hazard. Mater. 2021, 411, 125079. [CrossRef] 
24. Cormier, B.; Le Bihanic, F.; Cabar, M.; Crebassa, J.C.; Blanc, M.; Larsson, M.; Dubocq, F.; Yeung, L.; Clérandeau, C.; Keiter, S.H.; et al. Chronic feeding exposure to virgin and spiked microplastics disrupts essential biological functions in teleost fish. J. Hazard. Mater. 2021, 415, 125626. [CrossRef] [PubMed]

25. Perez-Venegas, D.J.; Valenzuela-Sánchez, A.; Montalva, F.; Pavés, H.; Seguel, M.; Wilcox, C.; Galbán-Malagón, C. Towards understanding the effects of oceanic plastic pollution on population growth for a South American fur seal (Arctocephalus australis australis) colony in Chile. Environ. Pollut. 2021, 279, 116881. [CrossRef] [PubMed]

26. Bochicchio, D.; Panizon, E.; Monticelli, L.; Rossi, G. Interaction of hydrophobic polymers with model lipid bilayers. Sci. Rep. 2017, 7, 1-9. [CrossRef]

27. Amelia, T.S.M.; Khalik, W.M.A.W.M.; Ong, M.C.; Shao, Y.T.; Pan, H.J.; Bhubalan, K. Marine microplastics as vectors of major ocean pollutants and its hazards to the marine ecosystem and humans. Prog. Earth Planet. Sci. 2021, 8. [CrossRef]

28. Grant, M.L.; Lavers, J.L.; Hutton, I.; Bond, A.L. Seabird breeding islands as sinks for marine plastic debris. Environ. Pollut. 2021, 276, 116734. [CrossRef]

29. Pop, C.E.; Draga, S.; Măciucă, R.; Niță, R.; Crăciun, N.; Wolff, R. Bisphenol a effects in aqueous environment on lemna minor. Processes 2021, 9, 1512. [CrossRef]

30. Oehlmann, J.; Schulte-Oehlmann, U.; Kloas, W.; Jagnytsch, O.; Lutz, I.; Kusk, K.O.; Wollenberger, L.; Santos, E.M.; Paull, G.C.; VanLook, K.J.W.; et al. A critical analysis of the biological impacts of plasticizers on wildlife. Philos. Trans. R. Soc. B Biol. Sci. 2009, 364, 2047-2062. [CrossRef]

31. Lebreton, L.C.M.; Van Der Zwet, J.; Damsteeg, J.W.; Slat, B.; Andrady, A.; Reisser, J. River plastic emissions to the world's oceans. Nat. Commun. 2017, 8, 15611. [CrossRef] [PubMed]

32. Franco, A.A.; Arellano, J.M.; Albendín, G.; Rodríguez-Barroso, R.; Quiroga, J.M.; Coello, M.D. Microplastic pollution in wastewater treatment plants in the city of Cádiz: Abundance, removal efficiency and presence in receiving water body. Sci. Total Environ. 2021, 776, 145795. [CrossRef]

33. Biagi, E.; Musella, M.; Palladino, G.; Angelini, V.; Pari, S.; Roncari, C.; Scicchitano, D.; Rampelli, S.; Franzellitti, S.; Candela, M. Impact of plastic debris on the gut microbiota of caretta caretta from Northwestern Adriatic sea. Front. Mar. Sci. 2021, 8. [CrossRef]

34. De-la-Torre, G.E.; Dioses-Salinas, D.C.; Pizarro-Ortega, C.I.; Santillán, L. New plastic formations in the Anthropocene. Sci. Total Environ. 2021, 754, 142216. [CrossRef] [PubMed]

35. Feng, S.; Lu, H.; Liu, Y. The occurrence of microplastics in farmland and grassland soils in the Qinghai-Tibet plateau: Different land use and mulching time in facility. Environ. Pollut. 2021, 279, 116939. [CrossRef]

36. Beriot, N.; Peek, J.; Zornoza, R.; Geissen, V.; Huerta, E. Science of the Total Environment Low density-microplastics detected in sheep faeces and soil: A case study from the intensive vegetable farming in Southeast Spain. Sci. Total Environ. 2021, 755, 142653. [CrossRef]

37. Cox, K.D.; Covernton, G.A.; Davies, H.L.; Dower, J.F.; Juanes, F.; Dudas, S.E. Human consumption of microplastics. Environ. Sci. Technol. 2019, 53, 7068-7074. [CrossRef]

38. Hennicke, A.; Macrina, L.; Malcolm-mckay, A.; Miliou, A. Assessment of microplastic accumulation in wild Paracentrotus lividus, a commercially important sea urchin species, in the Eastern Aegean. Reg. Stud. Mar. Sci. 2021, 45, 101855. [CrossRef]

39. Correia, J.; João, P.; Lopes, I.; Duarte, A.C.; Rocha-santos, T. Science of the Total Environment Environmental exposure to microplastics: An overview on possible human health effects. Sci. Total Environ. 2020, 702, 134455. [CrossRef]

40. ONU. Informe de la Conferencia de las Naciones Unidas sobre el Medio Ambiente y el Desarrollo; ONU: New York, NY, USA, 1993; pp. 1-68, ISBN 92-1-300143-6.

41. European Comission. Investing in Sustainable Development. The EU at the Forefront in Implementing the Addis Ababa Action Agenda; Office of the European Union: Brussels, Belgium, 2018; pp. 1-128. [CrossRef]

42. ONU. Draft Outcome Document of the United Nations Summit for the Adoption of the Post-2015 Development Agenda; United Nations: New York, NY, USA, 2015; pp. 1-41. Available online: https:/ /digitallibrary.un.org/record/803344\#record-files-collapse-header (accessed on 10 April 2021).

43. European Comission. The European Green Deal. COM(2019) 640 Final. 11.12.2019; Office of the European Union: Brussels, Belgium, 2019; pp. 1-28. Available online: https:/ / eur-lex.europa.eu/legal-content/en/ALL/?uri=CELEX:52019DC0640 (accessed on 13 March 2021).

44. European Commission. Closing the loop-An EU action plan for the Circular Economy. COM(2015) 614 final. 2.12.2015; Office of the European Union: Brussels, Belgium, 2015; pp. 1-5. Available online: https://eur-lex.europa.eu/legal-content/EN/TXT/?uri= CELEX:52015DC0614 (accessed on 13 March 2021).

45. European Commission. A New Circular Economy Action Plan For a Cleaner and More Competitive Europe. COM/2020/98 Final; Office of the European Union: Brussels, Belgium, 2020; pp. 1-20. Available online: https://eur-lex.europa.eu/legal-content/en/ALL/ ?uri=CELEX:52020DC0098 (accessed on 13 March 2021).

46. European Union. Directive (EU) 2019/904 of the European Parliament and of the Council of 5 June 2019 on the reduction of the impact of certain plastic products on the environment. Off. J. Eur. Union L ser. 2019, 155, 1-19.

47. European Union. Directive (EU) 2018/851 of the European Parliament and of the Council of 30 May 2018 amending Directive 2008/98/EC on Waste. Off. J. Eur. Union L ser. 2018, 150, 109-140. 
48. European Union. Directive (EU) 2018/852 of the European Parliament and of the Council of of 30 May 2018 amending Directive 94/62/EC on packaging and packaging waste. Off. J. Eur. Union L Ser. 2018, 150, 141-154.

49. European Union. Commission Decision of 3 May 2000 replacing Decision 94/3/EC establishing a list of wastes pursuant to Article 1(a) of Council Directive 75/442/EEC on waste and Council Decision 94/904/EC establishing a list of hazardous waste pursuant to Article 1(4) of Council Directive 91/689/EEC on hazardous waste. Off. J. Eur. Union L Ser. 2000, $226,3-24$.

50. European Union. Directive 2008/98/EC of 19 November 2008 on waste and repealing certain Directives. Off. J. Eur. Union L Ser. 2008, 312, 3-30.

51. European Union. EIP-AGRI Focus Group Circular Horticulture; Office of the European Union: Brussels, Belgium, 2017; pp. 1-18. Available online: https:/ / ec.europa.eu/eip/agriculture/en/publications/eip-agri-focus-group-circular-horticulture (accessed on 7 March 2021).

52. MAPA. Encuesta sobre Superficies y Rendimientos de Cultivos; Ministerio de Agricultura, Pesca y Alimentación: Madrid, Spain, 2020; pp. 1-45. Available online: https://www.mapa.gob.es/es/estadistica/temas/estadisticas-agrarias/totalespanayccaa2020_tcm30553610.pdf (accessed on 16 March 2021).

53. Junta de Andalucía. Cartografía de Invernaderos en Almería, Granada y Málaga. Año 2020; Consejería de Agricultura, Ganadería, Pesca y Desarrollo Sostenible: Sevilla, Spain, 2020; pp. 1-24. Available online: https://www.juntadeandalucia.es/export/ drupaljda/producto_estadistica/19/06/Cartografia\%20_inv_AL_GR_MA_v201127.pdf (accessed on 16 March 2021).

54. Camacho-Ferre, F. Técnicas de Producción de Cultivos Protegidos (Tomo I); Caja Rural Intermediterránea, Cajamar: Almería, Spain, 2004; pp. 1-373, ISBN 84-95531-15-1.

55. Cajamar. Análisis de la Campaña Hortofrutícola 2019/2020; Cajamar Caja Rural: Almerría, Spain, 2020; pp. 1-9. Available online: https:/ / www.plataformatierra.es/conocimiento/analisis-campana-hortofruticola / (accessed on 16 March 2021).

56. Baudoin, W.; Nersisyan, A.; Shamilov, A.; Hodder, A.; Gutierrez, D.; Pascale, S.D.E.; Nicola, S.; Chairperson, V.; Gruda, N.; Urban, L. Good Agricultural Practices for Greenhouse Vegetable Production in the South East European Countries; Food and Agriculture Organization of the United Nations: Rome, Italy, 2017; pp. 1-449, ISBN 978-92-5-109622-2.

57. Aznar-Sánchez, J.A.; Velasco-Muñoz, J.F.; García-Arca, D.; López-Felices, B. Identification of opportunities for applying the circular economy to intensive agriculture in Almería (South-East Spain). Agronomy 2020, 10, 1499. [CrossRef]

58. Duque-Acevedo, M.; Belmonte-Ureña, L.J.; Plaza-Úbeda, J.A.; Camacho-Ferre, F. The management of agricultural waste biomass in the framework of circular economy and bioeconomy: An opportunity for greenhouse agriculture in Southeast Spain. Agronomy 2020, 10, 489. [CrossRef]

59. Duque-Acevedo, M.; Belmonte-Ureña, L.J.; Toresano-Sánchez, F.; Camacho-Ferre, F. Biodegradable raffia as a sustainable and cost-effective alternative to improve the management of agricultural waste biomass. Agronomy 2020, 10, 1261. [CrossRef]

60. García-Raya, P.; Ruiz-Olmos, C.; Marín-Guirao, J.I.; Asensio-Grima, C.; Tello-Marquina, J.C.; de Cara-García, M. Greenhouse soil biosolarization with tomato plant debris as a unique fertilizer for tomato crops. Int. J. Environ. Res. Public Health 2019, 16, 279. [CrossRef]

61. Egea, F.J.; Torrente, R.G.; Aguilar, A. An efficient agro-industrial complex in Almería ( Spain ): Towards an integrated and sustainable bioeconomy model. N. Biotechnol. 2017, 40, 103-112. [CrossRef]

62. Castro, A.J.; López-Rodríguez, M.D.; Giagnocavo, C.; Giménez, M.; Céspedes, L.; La Calle, A.; Gallardo, M.; Pumares, P.; Cabello, J.; Rodríguez, E.; et al. Six collective challenges for sustainability of Almería greenhouse horticulture. Int. J. Environ. Res. Public Health 2019, 16, 4097. [CrossRef]

63. García, R. Use of Alternative Materials for Plastic Mulching Films Technical E Business Feasibility; Consejería de Agricultura, Ganadería, Pesca y Desarrollo Sostenible y COEXPHAL: Almería, Spain, 2020; pp. 1-18.

64. García, R. Energy Recovery of Difficult-to-Manage Waste Pilot Action Factsheet: Technical E Business Feasibility; Consejería de Agricultura, Ganadería, Pesca y Desarrollo Sostenible y COEXPHAL: Almería, Spain, 2020; pp. 1-16.

65. García, R. Comparison of Different Associative Waste Management Levels Pilot Action Factsheet: Technical E Business Feasibility; Consejería de Agricultura, Ganadería, Pesca y Desarrollo Sostenible y COEXPHAL: Almería, Spain, 2020; pp. 1-24.

66. Ufarte, A. Use of Alternative Materials for Plastic Staking Elements Pilot Action Factsheet: Technical \& Business Feasibility; Consejería de Agricultura, Ganadería, Pesca y Desarrollo Sostenible y COEXPHAL: Almería, Spain, 2020; pp. 1-15.

67. Ufarte, A. Waste Traceability Management Systems Pilot Action Factsheet: Technical E Business Feasibility; Consejería de Agricultura, Ganadería, Pesca y Desarrollo Sostenible y COEXPHAL: Almería, Spain, 2020; pp. 1-18.

68. Chen, S.; Gao, R.; Xiang, X.; Yang, H.; Ma, H.; Zheng, T.; Xiao, Y.; Zhang, X.; Li, H.; Fan, G.; et al. Straw mulching and nitrogen application altered ammonia oxidizers communities and improved soil quality in the alkaline purple soil of southwest China. AMB Express 2021, 11, 52. [CrossRef]

69. Anzalone, A.; Cirujeda, A.; Aibar, J.; Pardo, G.; Zaragoza, C. Effect of biodegradable mulch materials on weed control in processing tomatoes weed management-Techniques. Weed Technol. 2010, 24, 369-377. [CrossRef]

70. Valera-Martínez, D.L.; Belmonte-Ureña, L.J.; Molina Aiz, F.D.; Camacho-Ferre, F. The greenhouses of Almería, Spain: Technological analysis and profitability. Acta Hortic. 2017, 1170, 219-226. [CrossRef]

71. Callejón, A.J.; Carreño, A.; Sánchez-Hermosilla, J.; Pérez, J. Evaluación de impacto ambiental de centro de transformación y gestión de residuos sólidos agrícolas en la provincia de Almería (España). Inf. Constr. 2010, 62, 79-93. [CrossRef]

72. Espí, E.; Salmerón, A.; Fontecha, A.; García, Y.; Real, A.I. Plastic films for agricultural applications. J. Plast. Film Sheeting 2006, 22, 85-102. [CrossRef] 
73. MAGRAMA. Plan Estatal Marco de Gestión de Residuos PEMAR (2016-2022); Ministerio de Agricultura, Pesca y Alimentación: Madrid, Spain, 2015; pp. 1-182. Available online: https:/ /www.miteco.gob.es/es/calidad-y-evaluacion-ambiental/planes-yestrategias/Planes-y-Programas.aspx (accessed on 18 April 2021).

74. ACRR. Guía de Buenas Prácticas Para el Reciclahe de los Residuos Plásticos. Una Guía por y Para las Autoridades Locales y Regionales; Asociación de Ciudades y Regiones para el Reciclaje, Asociación de Fabricantes de Plásticos de Europa, Consejo Europeo de Fabricantes de Vinilo y Recicladores Europeos de Plásticos: Madrid, Spain, 2004; pp. 1-103. Available online: http: / / www.comunidadism.es/herramientas / guia-de-buenas-practicas-para-el-reciclaje-de-los-residuos-plasticos (accessed on 17 April 2021).

75. European Union. European Parliament and Council Directive 94/62/EC of 20 December 1994 on packaging and packaging waste. J. Eur. Com. L Ser. 1994, 365, 10-94.

76. Sigfito. Memoria Anual 2018; Sigfito: Madrid, Spain, 2018; pp. 1-10. Available online: http://sigfito.es/wp-content/uploads/20 19/07/Memoria_SIGFITO18.pdf (accessed on 21 April 2021).

77. Dupri, I. Estimación de los Residuos Agrícolas Generados en la Isla de Tenerife; Servicio Técnico de Agricultura y Desarrollo Rural de Tenerife: Tenerife, Spain, 2006; pp. 1-20. Available online: https:/ /www.agrocabildo.org/publicaciones_detalle.asp?id=28 (accessed on 23 March 2021).

78. Scarascia-Mugnozza, G.; Sica, C.; Russo, G. Plastic materials in European agriculture: Actual use and perspectives. J. Agric. Eng. 2012, 42, 15. [CrossRef]

79. Dupri, I. Guía para la Intervención Municipal Sobre Residuos Agrarios; Sociedad Cooperativa del Campo La Candelaria: Tenerife, Spain, 2008; pp. 1-102, ISBN 978-84-691-0126-1.

80. Dahl, M.; Bergman, S.; Björk, M.; Diaz-Almela, E.; Granberg, M.; Gullström, M.; Leiva-Dueñas, C.; Magnusson, K.; Marco-Méndez, C.; Piñeiro-Juncal, N.; et al. A temporal record of microplastic pollution in Mediterranean seagrass soils. Environ. Pollut. 2021, 273. [CrossRef]

81. Li, J.; Li, H.; Lin, D.; Li, M.; Wang, Q.; Xie, S.; Zhang, Y.; Liu, F. Effects of butyl benzyl phthalate exposure on Daphnia magna growth, reproduction, embryonic development and transcriptomic responses. J. Hazard. Mater. 2021, 404, 124030. [CrossRef]

82. Galdeano-Gómez, E.; Aznar-Sánchez, J.; Pérez-Mesa, J.C. Contribuciones Económicas, Sociales y Medioambientales de la Agricultura Intensiva de Almería; Cajamar Caja Rural: Almería, Spain, 2016; pp. 1-108, ISBN 13: 978-84-95531-74-2.

83. Fhalmería Horticultura intensiva de Almería. Anuario Agrícola 2018; FhAlmería: Almería, Spain, 2018; pp. 1-196. Available online: https: / / www.fhalmeria.com/descargar.aspx?seccion=noticia\&id=201 (accessed on 1 May 2021).

84. Junta de Andalucía. Seis Millones para Retirar Plásticos de Invernaderos Abandonados. Junta de Andalucía. 2018. Available online: http:/ / www.juntadeandalucia.es/presidencia/portavoz/tierraymar/136538/JuntadeAndalucia/ConsejeriadeAgricultura/ Invernaderos (accessed on 1 May 2021).

85. Junta de Andalucía. La Junta pone en Marcha una Campaña de Retirada de Plásticos Agrícolas en las Principales Zonas de Cultivo y Cauces Fluviales. Junta de Andalucía. 2018. Available online: http://www.juntadeandalucia.es/medioambiente/site/ portalweb/menuitem.30d4b35a97db5c61716f2b105510e1ca/?vgnextoid=cbdd3be747fe4610VgnVCM100000341de50aRCRD\& vgnextchannel=2229b8f8606b8210VgnVCM10000055011eacRCRD (accessed on 1 May 2021).

86. Junta de Andalucía. Listado de Gestores de Residuos Peligrosos y no Peligrosos. Junta de Andalucía. 2021. Available online: https://www.juntadeandalucia.es/medioambiente/portal/landing-page-\%C3\%ADndice/-_asset_publisher/zX2ouZa4 $\mathrm{r} 1 \mathrm{Rf} /$ content/gestores-de-residuos/20151?categoryVal= (accessed on 1 May 2021).

87. del García-García, M.C.; Céspedes López, A.J.; Pérez Parra, J.; Escudero, M.; Sánchez-Guerrero, M.; Medrano, E.; Baeza, E.; López, J.; Magán, J.J.; Fernández, M.D.; et al. El Sistema de Producción Hortícola Protegido de la Provincia de Almería; Instituto de Investigación y Formación Agraria y Pesquera: Sevilla, Spain, 2016; pp. 1-179. Available online: https://www.juntadeandalucia. es/agriculturaypesca/ifapa/servifapa/registro-servifapa/05ca752a-b1ff-4e6a-8c77-d706f90f20bc (accessed on 7 May 2021).

88. España. Real Decreto 1416/2001, de 14 de diciembre, sobre envases de productos fitosanitarios. Bol. Off. Del Estado 2001, 311, 50002-50004.

89. BINAS. Reciclado de Plásticos de Invernadero; Banco de ideas de Negocios Ambientales: Tenerife, Spain, 2014; pp. 1-19. Available online: https:/ / www.tenerife.es/portalcabtfe/images/PDF/temas/medio_ambiente/PlasticosInvernaderoJun15.pdf (accessed on 8 May 2021).

90. Ecoembes; Anarpla. Guía de buenas prácticas para la correcta gestión ambiental de los establecimientos de reciclado de envases plásticos; Ecoembes-Anarpla: Madrid-Valencia, España, 2018; pp. 1-68. Available online: https://anarpla.com/2019/guia-de-buenaspracticas-para-la-correcta-gestion-ambiental-de-los-establecimientos-de-reciclado-de-envases-plasticos/ (accessed on 15 May 2021).

91. Grau, A.; Farré, O. Situación y Potencial de Valorización Energénica Directa de Residuos. Estudio Técnico PER 2011-2020; Instituto para la Diversificación y Ahorro de la Energía: Madrid, Spain, 2011; pp. 1-132. Available online: https://www.idae.es/uploads/ documentos/documentos_11227_e15_residuos_c3ead071.pdf (accessed on 21 May 2021).

92. Ramos-Criado, A.; Ramos-Castellano, P. Gestión del Medio Ambiente (1996-2005). X Jornadas Ambientales; Ediciones Universidad de Salamanca: Salamanca, Spain, 2005; pp. 1-376, ISBN 9788478004799.

93. Fundación Laboral del Cemento y el Medio Ambiente. Reciclado y Valoración de Residuos en la Industria Cementera en España; Fundación Laboral del Cemento y el Medio Ambiente: Madrid, Spain, 2008; pp. 1-86. Available online: https://www. fundacioncema.org/wp-contentuploads201801informe_-iiestudiorsesectorcementero_min-pdf-2/ (accessed on 26 May 2021). 
94. Junta de Andalucía. Resolución de 14 Septiembre de 2007, del Delegado Provincial de la Consejería de Medioambiente en Almería, por la Que se Otorga Autorización Ambiental Integrada con el noaai/al/013/07, a la Empresa Holcim (España), S.A. para el Ejercicio de la Actividad de Lafabrica de Cemento de Carboneras (Almería) (EXP. AAI/AL/013). 2007. Available online: http:/ / webcache.googleusercontent.com/search?q=cache:XbbT2FdbkokJ:www.juntadeandalucia.es/medioambiente/ servtc1/AAIo/DownloadFileServlet\%3FcodigoAutorizacion\%3Daai_al_013_07+\&cd=1\&hl=es\&ct=clnk\&gl=es (accessed on 5 September 2021).

95. Junta de Andalucía. Manejo Final de los Envases de Fitosanitarios. Junta de Andalucía. 2014. Available online: https: //www.juntadeandalucia.es/agriculturapescaydesarrollorural/raif/es_ES/28/-/asset_publisher/10b6oYXQMbSK/content/ manejo-final-de-los-envases-de-fitosanitarios-?inheritRedirect=false\&redirect=http $\% 3 \mathrm{~A} \% 2 \mathrm{~F} \% 2 \mathrm{Fwww}$.juntadeandalucia.es / agriculturapescaydesar (accessed on 28 May 2021).

96. Junta de Andalucía. Plan Integral de Residuos de Andalucía. Hacia una Economía Circular en el Horizonte 2030; Junta de Andalucía: Sevilla, Spain, 2021; pp. 1-354. Available online: https://www.juntadeandalucia.es/medioambiente/portal/landing-pageplanificacion/-/asset_publisher/Jw7AHImcvbx0/content/plan-integral-de-residuos-de-andaluc-c3-ada/20151 (accessed on 14 May 2021).

97. Junta de Andalucía. Informe Sobre Producción y Gestión de Residuos no Peligrosos en Andaucía. Año 2018. Datos Definitivos; Junta de Andalucía: Sevilla, Spain, 2019; pp. 1-56. Available online: https://surminas.org/webs/default/media/Alegaciones/Informe\% 20PyG\%20RnoP\%202018.pdf (accessed on 3 May 2021).

98. Di, I.; Ventorino, V.; Cozzolino, E.; Ottaiano, L.; Romano, I.; Giuseppe, L.; Pepe, O.; Mori, M. Biodegradable mulching vs traditional polyethylene film for sustainable solarization: Chemical properties and microbial community response to soil management. Appl. Soil Ecol. 2021, 163, 103921. [CrossRef]

99. Candido, V.; Miccolis, V.; Castronuovo, D.; Manera, C. Eco-compatible plastic films for crop mulching and soil solarization in greenhouse. Acta Hortic. 2007, 751, 513-520. [CrossRef]

100. Marín-Guirao, J.I.; Tello-Marquina, J.C. Microbiota edáfica y fatiga de suelo en invernaderos de la provincia de Gran. In I Jornadas de Transferencia Hortofrutícola de CIAMBITAL; Camacho-Ferre, F., Valera-Martínez, D.L., Belmonte-Ureña, L., Herrero-Sánchez, C., Reca-Cardeña, J., Marín-Membrive, P., del Pino-Gracia, A., Casa-Fernández, M., Eds.; Investigación y Experimentación en Ciencias Agroalimentarias en el Sureste Español: Almería, Spain, 2017; pp. 17-36, ISBN 978-84-16389-98-8.

101. Guerrero, M.M.; Guirao, P.; Martinez-lluch, M.C.; Tello, J.C.; Lacasa, A. Soil fatigue and its specificity towards pepper plants in greenhouses. Spanish J. Agric. Res. 2014, 12, 644-652. [CrossRef]

102. Valera-Martínez, D.L.; Belmonte-Ureña, L.J.; Molina Aiz, F.D.; López Martínez, A. Los Invernaderos de Almería. Análisis de su Tecnología y Rentabilidad; Cajamar Caja Rural: Almería, Spain, 2014; pp. 1-504, ISBN 978-84-95531-61-2.

103. Honoré, M.N.; Belmonte-Ureña, L.J.; Navarro-Velasco, A.; Camacho-Ferre, F. Profit analysis of papaya crops under greenhouses as an alternative to traditional intensive horticulture in Southeast Spain. Int. J. Environ. Res. Public Health 2019, 16, 2908. [CrossRef] [PubMed]

104. Schrader, J.A.; Grewell, D.; Graves, W. Bioplastics and biocomposites for sustainable horticultural containers: Performance and biodegradation in home compost. Acta Hortic. 2017, 1170, 1-8. [CrossRef]

105. Candido, V.; Castronuovo, D.; Miccolis, V. The use of biodegradable pots for the cultivation of POINSETTIA. Acta Hortic. 2011, 983, 1-8. [CrossRef]

106. Junta de Andalucía. Orden de 26 de mayo de 2015, por la que se aprueban en la Comunidad Autónoma de Andalucía las bases reguladoras para la concesión de subvenciones a la Medida 10: Agroambiente y Clima, incluida en el Programa de Desarrollo Rural de Andalucía 2014-2020. Bol. Off. la Junta Andalucía 2015, 102, 10-62.

107. Junta de Andalucía. Orden de 6 de abril de 2017, por la que se modifican las Órdenes de 26 de mayo de 2015, por la que se aprueban en la Comunidad Autónoma de Andalucía las bases reguladoras para la concesión de subvenciones a la Medida 10: Agroambiente y Clima, y Medida 11. Bol. Off. la Junta Andalucía 2017, 69, 96-117.

108. Ministerio de Agricultura, Pesca y Alimentación. Desarrollo de la normativa relativa a la acción 7.18 incluida en las directrices medioambientales que forman parte de la Estrategia Nacional de Programas Operativos Sostenibles. Ministerio de Agricultura, Pesca y Alimentación. 2019. Available online: https://www.juntadeandalucia.es/export/drupaljda/Nuevos_importes_ Directrices_Medioambientales_7_2_11_18_19.pdf (accessed on 20 May 2021).

109. Ministerio de Agricultura, Pesca y Alimentación. Desarrollo de la normativa relativa a la acción 7.29 incluida en las directrices medioambientales que forman parte de la Estrategia Nacional de Programas Operativos Sostenibles. Ministerio de Agricultura, Pesca y Alimentación. 2019. Available online: https: / /www.mapa.gob.es/es/agricultura/temas/regulacion-de-los-mercados/ importesplasticosbiodegradablesycompostables_tcm30-559562.pdf (accessed on 20 May 2021).

110. MAPAMA. Estrategia Nacional de los Programas Operativos Sostenibles a Desarrollar por las Organizaciones de Productores, Frutas y Hortalizas; Ministerio de Agricultura, Pesca y Alimentación y Medio Ambiente: Madrid, Spain, 2017; pp. 1-275. Available online: https:/ / www.mapa.gob.es/es/agricultura/temas/regulacion-de-los-mercados/organizaciones-comunes-de-mercadoy-regimenes-de-ayuda/sector-hortofruticola/programas-operativos.aspx (accessed on 12 May 2021).

111. Sanchez-Hernandez, J.C.; Capowiez, Y.; Ro, K.S. Potential use of earthworms to enhance decaying of biodegradable plastics. ACS Sustain. Chem. Eng. 2020, 8, 4292-4316. [CrossRef]

112. Blouin, M.; Hodson, M.E.; Delgado, E.A.; Baker, G.; Brussaard, L.; Butt, K.R.; Dai, J.; Dendooven, L.; Peres, G.; Tondoh, J.E.; et al. Review of earthworm impact on soil function and. Eur. J. Soil Sci. 2013, 161-182. [CrossRef] 
113. Postma-Blaauw, M.B.; Bloem, J.; Faber, J.H.; Willem, J.; Groenigen, V.; De Goede, R.G.M.; Brussaard, L. Earthworm species composition affects the soil bacterial community and net nitrogen mineralization. Pedobiologia 2006, 50, 243-256. [CrossRef]

114. Zhang, M.; Zhao, G.; Li, Y.; Wang, Q.; Dang, P.; Qin, X.; Zou, Y.; Chen, Y.; Siddique, K.H.M. Straw incorporation with ridge-furrow plastic film mulch alters soil fungal community and increases maize yield in a semiarid region of China. Appl. Soil Ecol. 2021, 167, 104038. [CrossRef]

115. Junta de Andalucía. Estrategia Andaluza de Bioeconomía Circular; Junta de Andalucía: Sevilla, Spain, 2018; pp. 1-354. Available online: https://www.juntadeandalucia.es/export/drupaljda/Estrategia_Andaluza_Bioeconomia_Circular_EABC_18.09.2018 .pdf (accessed on 12 May 2021).

116. Cobacho-Vargas, A.; Martínez-Navarro, E.; Lorbach-Kelle, M.; García-Collado, R.; Chauveau, J.; Chiappini, G.; Mezzogori, D.; Groëll, F.; Combre, C.; Deloche, Y.; et al. REmanufacture the Food Supply Chain by Testing INnovative Solutions for Zero Inorganic WASTE; CRITT PACA: Brussels, Belgium, 2021; pp. 1-116, ISBN 3369937301.

117. Espí, E. Materiales de cubierta para invernaderos. In Cuadernos de Estudios Agroalimentarios; Almería España: Madrid, Spain, 2012; pp. 71-88. ISSN 2173-7568.

118. MA Business Ltd. BASF launches IrgaCycle additive solutions for mechanical recycling of plastics. Angew. Chem. Int. 2021, 9, 1-2. [CrossRef]

119. European Comission. A European Strategy for Plastics in a Circular Economy.COM (2018) 28 Final. 16.1.2018; Office of the European Union: Brussels, Belgium, 2018; pp. 1-19. Available online: https:/ / eur-lex.europa.eu/legal-content/EN/TXT/?uri=COM\%3A2 018\%3A28\%3AFIN (accessed on 26 February 2021).

120. ANARPLA. Boletín de Precios y Tendencias. Junio 2016 (1/2016); ANARPLA: Valencia, Spain, 2016; pp. 1-2.

121. PlasticsEurope. El Plástico en las Aplicaciones Agrícolas. PlasticsEurope. 2021. Available online: https:/ / www.plasticseurope. org/es/about-plastics/agriculture (accessed on 9 May 2021).

122. Ángeles Blazquez, M. Los residuos plásticos agrícolas. In Los Residuos Urbanos y Asimilables; Junta de Andalucia, Ed.; Junta de Andalucía: Sevilla, Spain, 2011; pp. 307-326. Available online: https://www.juntadeandalucia.es/medioambiente/web/Bloques_ Tematicos/Educacion_Y_Participacion_Ambiental/Educacion_Ambiental/Educam/Educam_IV/MAU_RU_y_A/rua10.pdf (accessed on 29 May 2021).

123. Billen, P.; Khalifa, L.; Van Gerven, F.; Tavernier, S.; Spatari, S. Science of the Total Environment Technological application potential of polyethylene and polystyrene biodegradation by macro-organisms such as mealworms and wax moth larvae. Sci. Total Environ. 2020, 735, 139521. [CrossRef] [PubMed]

124. Bombelli, P.; Howe, C.J. Polyethylene bio-degradation by caterpillars of the wax moth Galleria mellonella. Curr. Biol. 2017, 27, R292-R293. [CrossRef] [PubMed]

125. Peydaei, A.; Bagheri, H.; Gurevich, L.; De Jonge, N.; Nielsen, J.L. Comparative biochemistry and physiology-Part D impact of polyethylene on salivary glands proteome in Galleria melonella. Comp. Biochem. Physiol. Part D 2020, 34, 100678. [CrossRef]

126. European Comission. Plastic Waste and Recycling in the EU: Facts and Figures. European Comission. 2018. Available online: https:/ / www.europarl.europa.eu/news/en/headlines/society/20181212STO21610/plastic-waste-and-recycling-inthe-eu-facts-and-figures (accessed on 3 September 2021).

127. Merrington, A. 9 Recycling of plastics. In Applied Plastics Engineering Handbook; Elsevier Inc.: Midland, TX, USA, 2015; pp. 165-190, ISBN 9780323390408.

128. Herri, O.E.T.A.; Saila, A. El Petróleo y la Energía en la Economía; Servicio Central de Publicaciones del Gobierno Vasco: San Sebastián, Spain, 2008; pp. 1-296, ISBN 9788445727041.

129. Arandes, J.M.; Bilbao, J.; López-Valerio, D. Reciclado de residuos plásticos. Rev. Iberoam. Polímeros 2004, 5, $28-45$.

130. Plastics Europe. Plásticos-Situación en 2019. Plast. Eur. 2019. Available online: https://plasticseurope.org/es/plasticos-situacionen-2019/ (accessed on 28 February 2021).

131. Jeswani, H.; Krüger, C.; Russ, M.; Horlacher, M.; Antony, F.; Hann, S.; Azapagic, A. Life cycle environmental impacts of chemical recycling via pyrolysis of mixed plastic waste in comparison with mechanical recycling and energy recovery. Sci. Total Environ. 2021. [CrossRef]

132. Silva, A.L.P.; Prata, J.C.; Duarte, A.C.; Soares, A.M.V.M.; Barceló, D.; Rocha-Santos, T. Microplastics in landfill leachates: The need for reconnaissance studies and remediation technologies. Case Stud. Chem. Environ. Eng. 2021, 3, 100072. [CrossRef] 